\title{
Time Series Investigation of J-Curve of Pakistan with Saudi Arabia
}

\author{
Sana Suleman ${ }^{1}$, Dr. Ahmad Raza Cheema ${ }^{1}$, Muhammad Faraz Riaz ${ }^{2, *}$, Mahr Muhammd Yousaf ${ }^{1}$, Anam Shehzadi ${ }^{2}$ \\ ${ }^{1}$ Department of Economics, University of Sargodha, Punjab- Pakistan \\ ${ }^{2}$ Department of Economics, Government College University Faisalabad, Punjab-Pakistan \\ *Corresponding author: fraz.riaz@gmail.com
}

Received October 29, 2014; Revised November 18, 2014; Accepted December 05, 2014

\begin{abstract}
This study is focused in analyzing the existence of J-curve phenomenon of Pakistan with Saudi Arabia by using the time series data from 1973 to 2010 . Order of integration of the variables is mix as some variables are $\mathrm{I}(0)$ and some are I(1). So, ARDL approach to cointegration is applied to find out the relationship between exchange rate and trade balance. Results in both models do not support the existence of J-curve. The conclusion which is drawn from these models is that depreciation is not useful tool in improving trade balance of Pakistan with Saudi Arabia. Pakistan has to fine some alternative way of improving trade balance with these countries.
\end{abstract}

Keywords: Pakistan, Saudia, J-curve, ARDL, trade, Cointegarion

Cite This Article: Sana Suleman, Dr. Ahmad Raza Cheema, Muhammad Faraz Riaz, Mahr Muhammd Yousaf, and Anam Shehzadi, "Time Series Investigation of J-Curve of Pakistan with Saudi Arabia." Journal of Finance and Economics, vol. 2, no. 6 (2014): 210-214. doi: 10.12691/jfe-2-6-2.

\section{Introduction}

Determining suitable exchange rate is one of the critical tasks for developing countries because exchange rate plays a vital role in the settlement of trade balance of any country in this regard exchange rate policy is used most frequently for correcting the BOT (Balance of Trade). The theory that explains the relationship of exchange rate depreciation and BOT is the theory of J-curve. (Xu and Bahmani-Oskooee, 2013).

The J-curve hypothesis specifies that after devaluation trade balance first deteriorates and then it improves afterward. Xu and Bahmani-Oskooee (2013) says that this effect is observed due to sticky prices of imported commodities. The standardized J-curve illustrates two effects; one is volume effect (VE) and other is price effect (PE). Price effect remains lower than volume effect. Gelan and Bahmani-Oskooee (2011) explained that normally trade volume does not show any short run change but long run changes. Trade balance improves by devaluation iff Marshal-Learner condition holds in long run which states that sum of Import and export elasticities should be greater than one, because at in such condition price effect is diminished that time and volume effect is dominant. When the marshal learner condition is fulfilled the exchange deterioration seems to be a favorable tool for improving trade balance in the long run. This state shows that exports of the country have the potential to compensate the imports. As a result the volume of imported commodities will decrease and export volume will increase as adjustments is made in the exchange rate. All this process will improve the trade balance.
Pakistan being a developing economy is facing persistent trade deficit her import bill has always been greater than her export earnings except two fiscal years i.e. 1951-52 and 1972-73. Two major attempts have been made in Pakistan to promote exports by devaluation; first in 1955-56 and second in 1971-72. Exchange rate is depreciating continuously with the dollar and is affecting the trade balance negatively. Now the question arises whether the J-curve hypothesis exists between these two variables or not. (Petrovic and Gligoric, 2010).

Rehman and Afzal (2003) suggested devaluation as an effective tool in correcting the trade balance when exchange rate with U.S dollar was Rs. 57.57. Contrarily, according to Khan and Aftab (2008) J-curve of Pakistan does not exist with Hong Kong, Germany, Italy, Spain and Netherland. (Hameed and Kanwal; 2010, Awan et al. 2012; Khan et al, 2012) drew the same conclusion that J-curve did not exist in the Pakistan economy. Literature shows conflicting views about the existence of J-curve for Pakistan economy. The basic objective of this study is to investigate if the J-curve hypothesis of Pakistan holds true with Saudi Arabia.

\section{Materials and Methods}

As this study is a time series analysis so to choose the suitable econometric technique of estimation first the order of integration for all the variables is checked. As a second step the ARDL cointegration is applied on both the models under concern after finding mix order of integration. The data is taken from the WDI and SBP for the period of 1973 to 2010 . 
The variables which are utilized in the study are as under:

LY,

LYS,

LTBS,

Natural log of Income of Pakistan

LRETS, Natural log of Real bilateral exchange Natural log of Income Of Saudi Arabia

Natural log of Trade balance of Pakistan with Saudi Arabia rate of Pakistan with Saudi Arabia

\subsection{The Auto Regressive Distributed Lag (ARDL) Frame Work}

ARDL approach is used for analysis as it does not care for the difference in order of integration of variables. This technique was introduced by Pesaran et al (2001). This is most flexible approach because it deals with the variables that having same or different orders of integration that is at level I (0) and first difference I (1) or mix.

The general form of the model:

$$
\begin{aligned}
Y_{t}= & \delta+\delta_{0} X_{i}+\delta_{1} X_{t-1}+\ldots \ldots+\delta_{p} X_{t-p} \\
& +\theta_{1} Y_{t-1}+\ldots \ldots+\theta_{p} Y_{t-p}+V_{i}
\end{aligned}
$$

This technique was introduced by Pesaran et al. (2001). ARDL is applied to compute the cointegration association of TB with real bilateral exchange rate. The model constructed to analyze the existence of J-curve phenomenon is as follow:

$$
\begin{aligned}
\operatorname{LTBT}_{t}= & \alpha_{1}+\sum_{i=1}^{p} \beta_{i} L_{T B T_{t-i}}+\sum_{i=0}^{q} \gamma_{i} L Y_{t-i} \\
& +\sum_{i=0}^{r} \delta_{i} L Y T_{t-i}+\sum_{i=0}^{s} \varepsilon_{i} L R E T_{t-i}+\mu_{t}
\end{aligned}
$$

\subsection{Error Correction Mechanism (ECM)}

The idea underlying error correction mechanism is basically to establish that the part of the disturbance is corrected form short run to the long run in a given economic situation (Engle and Granger, 1987). The Granger provided the basis of error correction model (ECM). This theorem gives framework for analyzing the cointegrated series. The accuracy of ECM depends on the relationship of the variables in the long run.

The consistency of estimates is attained through the inclusion of long run effects and short run dynamics. The main advantage of ECM is that it includes the differenced terms. All the stationary terms included in the analysis and it ensures that no information on the levels of variables is ignored by the addition of the disequilibrium terms. The ECM eliminates the trend by adding the variables at first difference and in this way the problem of spurious regression is removed.

The General Form of Unrestricted ECM model in ARDL (p,q,r) formulation:

$$
\begin{aligned}
\Delta L T B T_{t} & =\alpha_{0}+\sum_{i=1}^{p} \beta_{i} \Delta L T B T_{t-i}+\sum_{i=0}^{q} \gamma_{i} \Delta L Y_{t-i} \\
& +\sum_{i=0}^{r} \delta_{i} \Delta L Y T_{t-i}+\sum_{i=0}^{s} \varepsilon_{i} \Delta L R E T_{t-i} \\
& +\theta_{i} L T B T_{t-i}+\theta_{2} L Y_{t-i}+\theta_{3} L Y T_{t-i} \\
& +\theta_{4} L R E T_{t-i}+\mu_{t}
\end{aligned}
$$

The following ECM model in ARDL (p,q,r) formulation is estimated in this research.

$$
\begin{aligned}
& \Delta L T B T_{t}=\gamma_{1}+\delta_{1}(e c m)_{t-1}+\sum_{i=1}^{p} \alpha_{i}(\Delta L T B T)_{t-i} \\
& +\sum_{i=0}^{q} \beta_{i}(\Delta L Y)_{t-i}+\sum_{i=0}^{r} \varepsilon_{i}(\Delta L Y T)_{t-i}+\sum_{i=0}^{s} \omega_{i}(\Delta L R E T)_{t-i}
\end{aligned}
$$

\section{Results and Discussions}

\subsection{Model of Saudi Arabia and Pakistan}

\subsubsection{Results of the Unit Root Tests}

Augmented Dickey Fuller (ADF) test is applied to find out the order of integration of variables in this research.

Null hypothesis underlies that the coefficient has a unit root. The results are reported in the Table 1 . The unit root

\begin{tabular}{|c|c|c|c|c|c|}
\hline \multirow{2}{*}{ Dependent variable } & \multirow{2}{*}{ F-Statistics } & \multirow{2}{*}{ Lag } & \multicolumn{2}{|c|}{ F-critical value* } & \multirow{2}{*}{ Conclusion } \\
\hline & & & $\mathrm{I}(0)$ & $\mathrm{I}(1)$ & \\
\hline $\mathbf{F}_{\text {(Ltbs/ly,lys,lrets) }}$ & $F_{(4,7)}=16.9881$ & 5 & 3.219 & 4.378 & Cointegration \\
\hline $\mathbf{F}_{\text {(ly/lys,ltbs,lrets) }}$ & $F_{(4,7)}=1.2017$ & 5 & 3.219 & 4.378 & No Cointegration \\
\hline $\mathbf{F}_{(\mathrm{lys} / \mathrm{y}, \text { Itbs,Irets) }}$ & $F_{(4,7)}=1.7382$ & 5 & 3.219 & 4.378 & No Cointegration \\
\hline $\mathbf{F}_{\text {(lrets/ly,lys,ltbs, })}$ & $F_{(4,15)}=5.155$ & 5 & 3.219 & 4.378 & Cointegration \\
\hline
\end{tabular}
test(ADF test ) reveals that some variables are stationary at $1^{\text {st }}$ difference and one is at level.

Table 1. Unit Root Test for the Model

\begin{tabular}{|lcccc|}
\hline \multicolumn{4}{c}{ At Level } & \multicolumn{2}{c|}{ At $\mathbf{1}^{\text {st }}$ Difference } \\
\hline & Without trend & with trend & Without trend & with trend \\
\hline LTBS & -1.6494 & -2.3977 & $-6.7284^{*}$ & $-6.8835^{*}$ \\
\hline LY & -1.6654 & -1.2679 & $-2.8580^{* * *}$ & $-3.2819^{* * *}$ \\
\hline LYS & -0.3250 & -1.8736 & $-3.0617^{* *}$ & -2.9813 \\
\hline LRETS & 0.6846 & $-3.9096 *$ & $-3.4028^{*}$ & $-3.4028^{*}$ \\
\hline Note* ${ }^{* * * * * *},{ }^{* *}$ Indicates that variable is stationary at $1 \%, 5 \%, 10 \%$ level.
\end{tabular}

\subsubsection{Estimation of the Cointegrating Vector}

All the regressors are replaced as regress and to find out the number of cointegrating vectors in this model and the results are reported in Table 2.

Table 2. Lag Determination through bounds tests

Note: There are two cointegrating vectors. 
trade balance in Saudi Arabia. The long run results of the model are given in the Table 3.

Table 3. Results of Long run Relationship

\begin{tabular}{|lcccc|}
\hline Variables & Coefficients & Standard error & t-statistics & P-values \\
\hline C & 11.4648 & 4.9046 & $2.3356^{* *}$ & .045 \\
\hline LY & 5.0399 & 1.3513 & $3.7297^{*}$ & .002 \\
\hline LYS & -1.7893 & 1.0038 & $-1.7825 * * *$ & .006 \\
\hline LRETS & -2.0964 & 0.6476 & $-3.2369 *$ & .005 \\
\hline
\end{tabular}

Note*,**,***Indicates that variable is significant at $1 \%, 5 \%, 10 \%$ level.

Result show that domestic income is positively related with trade balance with the value of elasticity equal to
5.03. The coefficient of LYS is negative and significant which indicates that when income of Saudi Arabia increases the trade balance of Pakistan with Saudi Arabia will be effected negatively. The real bilateral exchange rate has negative and significant sign. It indicates that the Marshall -Learner condition does not hold in the long run. The J-curve hypothesis does not hold in the long run. So depreciation will worsen the trade balance of Pakistan in case of Saudi Arabia.

\subsubsection{Results of Error Correction Model}

Results of error correction model are reported in Table 4.

Table 4. ECM Short Run Results

\begin{tabular}{|c|c|c|c|c|}
\hline Variables & Coefficients & Standard error & t-statistics & Probability \\
\hline $\operatorname{ECM}(-1)$ & -.81173 & .1585 & $5.4938 *$ & 0.000 \\
\hline $\mathrm{C}$ & 9.9867 & 6.4286 & 1.5535 & .137 \\
\hline DLY & -9.8467 & 3.2909 & $2.9921 * *$ & 0.007 \\
\hline DLYS & -2.8979 & .9008 & $-3.2167 *$ & 0.005 \\
\hline DLRETS & -1.8261 & .5413 & $-3.3734 * *$ & 0.003 \\
\hline S.E. of Regression & .2187 & \multicolumn{2}{|c|}{ R-squared } & .8117 \\
\hline Durbin-W stat & 2.3562 & \multicolumn{2}{|c|}{ AdjustedR-squared } & .6456 \\
\hline Durbin- h statistic & 1.946 & \multicolumn{2}{|c|}{ F-statistic } & $5.6382[.000]$ \\
\hline
\end{tabular}

Note*,**,***Indicate significance at $1 \%, 5 \%, 10 \%$ level.

The value of error correction term $(-0.8117)$ is negative and significant statistically which means that the model is convergent in nature. Any disequilibrium arising in the short run will be adjusted in the long run within one year. $81.17 \%$ equilibrium will be restored in one year.

The intercept is positive and insignificant. It means when there is no change in other arguments the trade balance will improve by $9.98 \%$. The domestic income has negative sign and significant at $5 \%$ level of significance. This will show that when the domestic income increases it will detorirates the trade balance by 9.84 percent. It means in the short run the people will purchase more. The coefficient of foreign income DLYS is negative and significant at $1 \%$ level of significance. It means when the income of Saudi Arabia increases it will deteriorate the trade balance $2.89 \%$.

The coefficient of real bilateral exchange rate DLRETS is negative and significant at $5 \%$ level. It shows that when the depreciation done in the country the trade balance will deteriorate in the short run. The Marshall- Learner condition does not hold because the sign of DLRETS is negative, which is not according to the economic theory. The J-curve phenomenon holds in the short run because in the short run trade balance worse off and improves in the long run.

The combination of short run and long run findings gives no evidence of J-curve hypothesis. In the long run the Marshall -Learner condition does not hold. The sign does not go from negative to positive of LRETS real bilateral exchange rate. It shows that J-curve does not hold in the case of Pakistan with Saudi Arabia. The results are same as of Khan and Aftab (2008) interpreting that Jcurve did not exist of Pakistan with these countries Hong Kong, Germany, Italy, Spain and Netherland. The inference is also parallel with the findings of Hameed and Kanwal (2009).

\subsubsection{Generalized Impulse Response Functions}

Figure 1 shows that one S.D Innovation of LRETS has expansionary effect on trade balance of Pakistan.

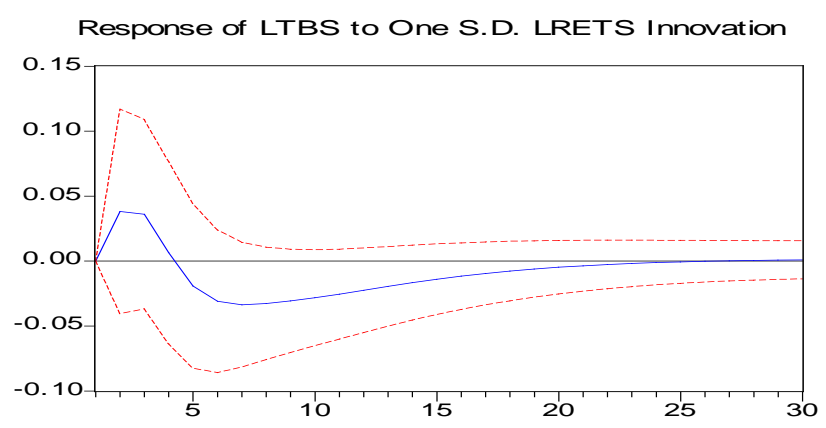

Figure 1. Response of LTBS to One S.D. LRETS Innovation

\subsubsection{Stability Test}

CUSUM and CUSUM of Squares tests are applied in this study to check the structural stability of estimated parameters. Results of both tests show that estimated parameters are stable over the study time as the CUSUM stat in both cases is within upper and lower limits constructed under 95\% confidence interval.

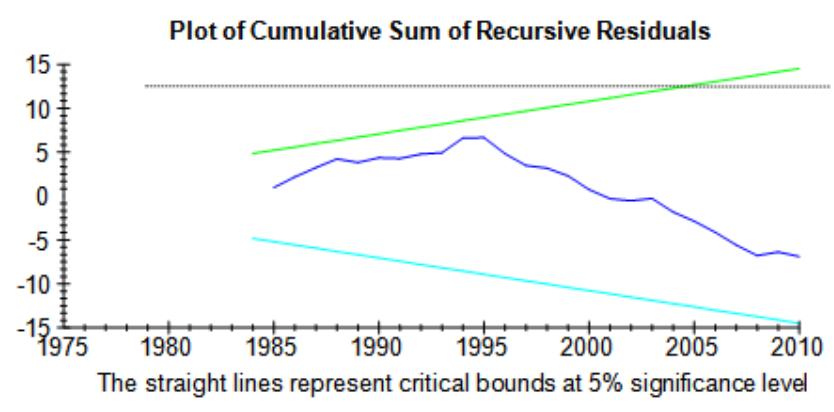

Figure 2. CUSUM Test for Structural Stability 
Plot of Cumulative Sum of Squares of Recursive Residuals

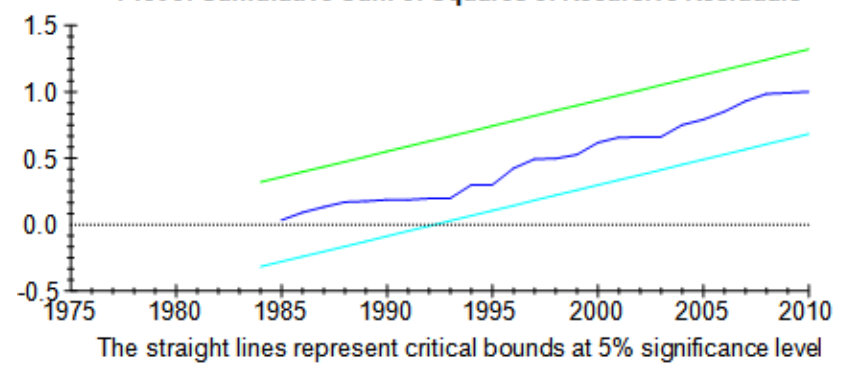

Figure 3. CUSUMSQ Test for Structural Stability

\section{Conclusion and Policy Suggestions}

Trade balance is now as in the era of globalization an important growth factor of the world economy. The countries that claim faster growth rate of GDP are considered successful and have been producing larger amount exports for the world economy. In developing countries the trade balance is helpful tool in achieving growth and development.

Empirical investigation of j-curve hypothesis showed that there exists no J-curve in Pakistan at least in case of Saudi Arabia. The possible reason for the non existence of $\mathrm{J}$-curve is the nature of exports of Pakistan as she is not an exporter of finished goods. So to correct the trade balance of Pakistan devaluation has not been proved a suitable tool. Pakistan needs specialization in producing the finished type of exportable products for earning high from exports. Primary product exports have no proper justification to be increased. Government of Pakistan should focus on improving the quality of exports accompanied with the exchange rate stabilization because devaluation of exchange rate is proves unfavorable.

\section{References}

[1] Afzal, M. (2004). Estimating long run trade elasticities in Pakistan: A Cointegration approach. The Pakistan Development Review, 43(4), 757-770.

[2] Ahtiala, P.(1981). When does the J-curve have a J-shape? Discussion paper no. 473, Center for Mathematical Studies in Economics and Management Science in its series, Northwestern University.

[3] Akbostanci, E. (2002). Dynamics of the trade balance: The Turkish J-curve. Working paper no.0205, ERC.

[4] Awan, R. U., Shahbaz, M., Sher, F.,and Javed, K., (2012). Does Jcurve Phenomenon exist in Pakistan? A Revisit. Interdisciplinary Journal Of Contemporary Research In Business,3(9), 1456-1467.

[5] Backus, D. K., Kehoe, P. J., and Kydland, F. E. (1994). Dynamics of the trade balance and the terms of trade: The J-curve?. The American Economic Review, 84(1), 84-103.

[6] Bahmani-Oskooee, M. (1985). Devaluation and the J-curve: Some evidence from LDCs. The Review of Economics and Statistics, 67 (3), 500-504

[7] Bahmani-Oskooee, M. and Brooks, T. J. (1999). Bilateral J-curve between US and Her Trading Partners. Weltwirtschaftliches Archives, 135(1), 156-165.

[8] Bahmani-Oskooee, M., and Ratha, A. (2004b). The J-curve Dynamics of US bilateral trade. Journal of Economics and Finance, 28, 32-38.

[9] Bahmani-Oskooee, M., and Kantipong, T. (2001). Bilateral Jcurve between Thailand and her trading partners. Journal of Economic Development, 26(2), 107-117.

[10] Bahmani-Oskooee, M., and Hegerty. (2009). The Nafta and Jcurve evidence From Commodity trade between U.S and Mexico, 43, 1579-1573.
[11] Bahmani-Oskooee, M., and Harvey., H. (2012). J-Curve: Singapore versus her Major Trading Partners. The Economic Society of Australia, 31(4), 515-522.

[12] Bahmani-Oskooee, M., and Xu, J. (2013). The J-Curve and Japan-China commodity trade. Journal of Chinese Economic and Business Studies, 11(1), 13-28.

[13] Bahmani-Oskooee. M., and Gelan, A.(2012). Is there J-Curve effect in Africa? International Review of Applied Economics, 26(1), 73-81.

[14] Betliy, O. (2002). Measurement of the real effective exchange rate and the observed J-curve: case of Ukraine.

[15] Bolhasani, M., and Bahmani-Oskooee. M. (2008). The J-curve: Evidence from commodity trade between Canada and the U.S. journal of economics and finance, 32, 207-225.

[16] Dickey, D. A., and Fuller, W. A. (1979). Distribution of the Estimator for Autoregressive Time Series with a Unit Root. Journal of the American statistical association. 74, 427-431.

[17] Dickey, D., and Fuller, W. (1979). Likelihood ratio statistics for autoregressive time series with a unit root. Econometrica, 1057-72.

[18] Goswami, G. G., Economidou, C., and Bahmani-Oskooee., M. (2006). Bilateral J-curve b4eetween the UK vis-à-vis her major trading partners. Applied Economics, 38, 879-888.

[19] Goswami, G., Bahmani-Oskooee, M., and Arora, S. (2010). Bilateral J-curve between India and her trading partners. Applied Economics, 35(9), 1037-1041.

[20] Hill, R. C., Griffiths, W.E., and Judge, G. G. (2001), Undergraduate Econometrics ( ${ }^{\text {nd }}$ Ed.). John Wiley \& Sons.Inc, United States of America.

[21] Gujarati, D.N. (1995). Basic Econometrics (3rd Ed.). McGrawHill International Editions.New York

[22] Gujrati, D.N. (2004). Basic Econometric, (4th Ed.). The McGrawHill Companies. NewYork.

[23] Halicioglu, F. (2007). The Bilateral J-curve: Turkey versus her 13 trading partners. Working paper no. 3564, MPRA.

[24] Halicioglu, F. (2008). The bilateral J-curve: Turkey versus her 13 trading partners. Journal of Asian Economics.19, 236-243.

[25] Halicioglu, F. (2008). The J-curve dynamics of Turkey: An application of ARDL model. Applied Economics. 40(18), 24232429.

[26] Hameed, A., and Kanwal, S. (2009). Existence of a J-curve -The Case of Pakistan. Journal of Economic Cooperation And Development, 30(2), 75-98.

[27] Handbook of statistics (various issues), Government of Pakistan, Federal bureau of statistics, Islamabad.

[28] Hatemi-J, A., and Hacker, R. S. (2003). Is the J-curve effect observable for small North European economies?. Open economies review, 14, 119-134.

[29] Hazel, P., kabaklarli, E., and Bulus, A. (2011). J- Curve and turkey economy: Real Exchange Rate And Influence Of Gdp On Foreign Trade. International Conference on Applied Economics.

[30] Hsing, M. H. (2005). Re-examination of J-curve effect for Japan, Korea and Taiwan. Japan and the World Economy, 17, 43-58.

[31] Hsing, Y. (2008). A Study of the J-curve for seven selected Latin American Countries.

[32] Hsing, Y. (2009). Test of the J-curve for the DR-CAFTA countries and policy implications. Research in International Business and Finance, 23, 293-301.

[33] Hsing, Y., and Sergi, B. S. (2009). An empirical test of the J-curve for Estonia, Latvia, And Lithuania and policy implications. Transformations in Business and Economics, 8(1), 63-71.

[34] Johansen, S. (1988). Statistical Analysis of Co-Integrating Vectors. Journal of Economic Dynamics and Control, 12, 231-254.

[35] Kamoto, B. E. (2006). The J-curve effect on the trade balance in Malawi and south Africa, Thesis, The Faculty of the Graduate School, The University of Texas at Arlington.

[36] Khan, M, Z., Shiekh, S, M., Ahmad, M., and Shahan, S.,(2012). The J-Curve phenomenon in Pakistan. Interdisciplinary Journal Of Contemporary Research In Business,3(9), 679-699.

[37] Kruger, A.O. (1978). Foreign Trade Regimes and Economic Development: Liberalization Attempts and Consequences. Working paper, Ballinger Publish Co. for NBER, Cambridge,

[38] Nadenichek, J. (2010). An empirical examination of trade and the $\mathrm{J}$-curve in an International real business cycle framework. Journal of International and Global Economic Studies, 3(2), 1-18.

[39] Onafowara, O., (2003). Exchange rate and trade balance in East Asia: Is there a J-curve? Economics Bulletin, 5(18), 1-13. 
[40] Pesaran M.H., and Pesaran, B. (1997). Working with Microfit 4.0 Interactive Econometric Analysis. Oxford, Oxford University Press.

[41] Pesaran, M.H., and Shin, Y. (1998). Generalized Impulse Response Analysis in Linear Multivariate Models. Economics Letters. 58 (1), 17-29.

[42] Pesaran, M.H., Shin, Y., and Smith, R.J. (2001). Bounds testing approaches to the analysis of level relationships. Journal of Applied Econometrics, 16 (3), 289-326.

[43] Petrovic, P., and Gligoric, M. (2010). Exchange Rate and Trade Balance: J-curve Effect. PANOECONOMICUS, 1, 23-41.

[44] Ramakrishnan, U., and Gupta-Kapoor. (1999). Is there a J-curve? a new estimation for Japan. International Economic journal, 13(4), 71-79.

[45] Ratha, A., and Kang, E. (2007). Asian financial crisis and the Jcurve: evidence from South Korea. Working paper 2007-1, Saint Cloud State University, department of Economics.
[46] Silva, S. D., and Guilherme, M. (2005). Is there a Brazilian J-Curve?. Economics Bulletin. 6(10), 1-17.

[47] Singh, T. (2004). Testing J-curve hypothesis and analyzing the effect of exchange rate volatility on the balance of trade in India. Empirical Economics, 29, 227-245.

[48] Griffiths, W.E, Carter, H. R., and Judge, G.G. (2001). Undergraduate Econometrics. $2^{\text {nd }}$ Edition, John Wiley and Sons, Inc.

[49] Wang,Y., and Bahmani-Oskooee, M. (2006). The J-curve: China versus her trading partners. Bulletin of Economic Research, 58(4), 323-348.

[50] Wilson, P. (2001). Exchange rates and the trade balance for dynamic Asian economies-Does the J-curve exist for Singapore, Malaysia, and Korea? Open Economies Review, 12(4), 389-413.

[51] Wilson, Peter. (2001). Exchange Rates and the Trade Balance for Dynamic Asian Economies-Does the J-curve Exist for Singapore, Malaysia and Korea?. Open Economies Review, 12, 389-413. 